\title{
The role of bovine preserved peritoneum in rats ventral hernia. A histological evaluation $^{1}$
}

\author{
Aspectos histológicos do uso do peritônio bovino conservado na correção de hérnia \\ ventral em ratos
}

\author{
Eduardo Lemos de Souza Bastos², Djalma José Fagundes ${ }^{3}$, Murched OmarTaha ${ }^{4}$, Neil Ferreira Novo ${ }^{5}$, Yara Juliano ${ }^{5}$, \\ Manuel de Jesus Simões ${ }^{6}$, Rubens Augusto Brazil Silvado ${ }^{7}$ \\ 1. Research performed at Postgraduate Program in Surgery and Experimentation of Federal University of São Paulo (UNIFESP), Brazil. \\ 2. Assistant Professor, Department of Surgery, Marilia Medicine School (FAMEMA), Brazil. \\ 3. Associate Professor, Department of Surgery of UNIFESP São Paulo, Coordinator of Postgraduate Program in Surgery and Experimentation, \\ UNIFESP, Brazil. \\ 4. Affiliate Professor, Department of Surgery, UNIFESP, Brazil. \\ 5. Associate Professor, Biostatistics Division, Department of Preventive Medicine, UNIFESP, Brazil. \\ 6. Assistant Professor, Head of Histology and Structural Biology Division, UNIFESP, Brazil. \\ 7. Assistant Professor, Department of Surgery, Head of Digestive Surgery Division, FAMEMA, Brazil.
}

\begin{abstract}
Purpose: To assess the role of preserved bovine parietal peritoneum as a material for hernia repair in a rat ventral hernia model. Methods: An abdominal wall defect $(15 \mathrm{~mm}$ x $25 \mathrm{~mm})$ was created in Wistar male rats $(\mathrm{n}=40)$. Control animals $(\mathrm{n}=20)$ had the polypropylene (PP) mesh sutured into the defect, whereas bovine preserved peritoneum (BPP) was used in experimental group $(n=20)$. After 7 and 28 days, the abdominal wall was taken off and histological studies of the amount of collagen by Sirius Red stain and morphometric evaluation consisted in quantitative analysis of the collagen by using specific software (Imagelab $\left.{ }^{\circledR}\right)$. The Mann-Whitney, Kruskal-Wallis and ANOVA tests were applied for statistical analysis (pd”0.05). Results: Histological examination revealed no difference between the BPP and PP groups ( $p=0.55$ NS). Conclusion: BPP is suitable for the closure of ventral hernias in rat model as shown by its morphological properties.
\end{abstract}

Key words: Hernia, Ventral. Peritoneum. Surgical, Mesh.

\section{RESUMO}

Objetivo: Estudar os aspectos histológicos do uso de uma prótese de peritônio bovino na correção de hérnia ventral em um modelo animal de doença. Métodos: Utilizando 40 ratos machos Wistar, comparou-se o implante do peritônio bovino com a tela de polipropileno na correção de um defeito provocado na parede abdominal do animal. Após 7 (sub-grupo A) e 28 (sub-grupo B) dias de observação, as peças foram retiradas e procedeu-se o estudo histológico através da quantificação de colágeno pelo método de captação e processamento digital de imagens, sob a coloração do Sirius Red. Os testes de Mann-Whitney, de Kruskal-Wallis e ANOVA foram utilizados e estabeleceu-se em 0,05 o nível para rejeição da hipótese de nulidade (pd”0.05). Resultados: A quantificação do colágeno na interface do implante mostrou equivalência entre os grupos Peritônio e Polipropileno ( $\mathrm{p}=0,55$ NS). Conclusão: O peritônio parietal bovino apresentou infiltração de tecido fibrocolágeno semelhante a da tela de polipropileno na correção de hérnia ventral em ratos.

Descritores: Hérnia Ventral. Peritnio. Telas Cirúrgicas.

\section{Introduction}

Surgical repair of large abdominal wall defects, such as ventral hernia, is still a difficult problem for surgeons. Treatment involves major surgery and the results may be poor. Since surgical meshes were introduced, they have become essential in hernioplasty as they have been associated with fewer recurrence rates by allowing tensionfree repair ${ }^{1,2}$. The most widely used material for abdominal wall replacement and reinforcement during hernia repair is polypropylene mesh (PP), a synthetic non-absorbable material $^{3}$. In experimental animals studies, PP is usually used as "control” (standard treatment) for comparison with others materials ${ }^{4,5}$. Although actually, PP mesh (as well as others synthetic non-absorbable meshes) suffers from a number of complications, including bowel adherence and obstruction, fistula formation, wound infection and seroma/ hematoma development $\mathrm{t}^{6,7,8,9,10,11}$. Biological surgical meshes are an attractive option for dealing with the difficulties. Fascia grafts ${ }^{12}$, preserved human dura ${ }^{13,14,15}$ and bovine pericardium ${ }^{16,17,18}$ are tissues utilized in the experiments and clinical practice. Infrequently, the human hernia $\operatorname{sac}^{19,20}$, amniotic membranes combined with non-absorbable 
synthetic material ${ }^{21}$ and extra cellular matrix, as porcine intestinal or dermal collagen, as human acellular dermal22, may be presented as options. The bovine parietal peritoneum (BPP), usually extracted from healthy animals, may be presented as an option by supplying a large amount of material in each collect procedure and the processes of preparing and storage are relatively inexpensive. BPP has already been employed in medical research ${ }^{23}$ and in veterinary medicine ${ }^{24,25,26}$. Over all, it seems to have more strength than peritoneum from others animals ${ }^{27}$. Therefore, the aim of this study is to assess the role of preserved BPP as a material for hernia repair in an experimental rat ventral hernia model.

\section{Methods}

The experiment was carried out at the Surgical Department of UNIFESP-EPM, Sao Paulo, Brazil. Guidelines for the care and use of laboratory animals were followed and the Committee on Animal Research approved the experimental protocol. Forty male Wistar rats weighing between 350-430g were acclimated to laboratory conditions for 7 days and fed a standard rat chow and water ad libitum. After overnight fasting general, anesthesia was performed with an intramuscularly application of a mixture of Ketamine [60mg. $\mathrm{Kg}^{-1}$ ] and Xylazine [5mg. $\mathrm{Kg}^{-1}$ ]. On day 0 (operation day), the animals were divided in two groups, according to the surgical mesh used for hernia repair. Surgical procedure: it was used a standardized ventral hernia model (fullthickness abdominal wall defects) with immediate repair by a surgical mesh. The abdominal wall defects (15mm x 25mm) were repaired in 20 rats with BPP (group 1) and with PP mesh in the other 20 ones (group 2). The surgical mesh was sutured to the abdominal wall by onlay technique using interrupted 5-0 catgut sutures. Skin closure with continuous 4-0 nylon sutures was performed. All rats were maintained post-operatively with food and water ad libitum and no wound dressings were used. No antibiotics were given to any animal either. The animals were further divided into subgroups of 10 rats each and euthanasia was performed on $7^{\text {th }}$ and $28^{\text {th }}$ days after operation (subgroups $7^{\text {th }} \mathrm{PO}$ and $28^{\text {th }} \mathrm{PO}$, respectively). Afterwards, the mesh, without skin, was excised with the surrounding abdominal wall muscles and a piece including the surgical mesh, the interface and normal abdominal wall was prepared to histological examination. Histological examination: specimens were fixed in $10 \%$ formaldehyde and embedded in paraffin. Sections of $5 \mu \mathrm{m}$ were obtained and stained with Sirius-Red, to determine abundance and distribution of collagen fiber tissue. Sirius red only stains collagen fibers in red. The morphometric evaluation consisted in quantitative analyses of the collagen by using specific software (Imagelab ${ }^{\circledR}$ ), which is able to trap and processes the images, by RGB (red-green-blue) screen, in order to count the amount of collagen per camp, based on amount of color (spectrophotometry). With non-polarized light microscopy, all types of collagen (mainly type I and III) are viewed by red color. The morphometric evaluation was carried out in mesh-tissue interface with 40x light microscopy (Figures 1 and 2), trapping five camps per lamina and performing final media per animal.

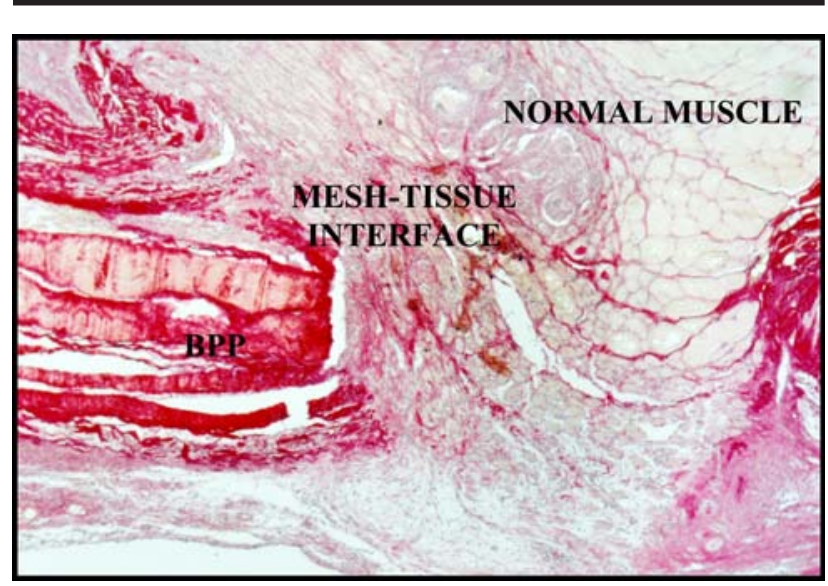

FIGURE 1 - Histological section of rat from BPP group showing the interface where the images were trapped for morphometric evaluation consisted in quantitative analyses of the collagen, under staining with Sirius Red

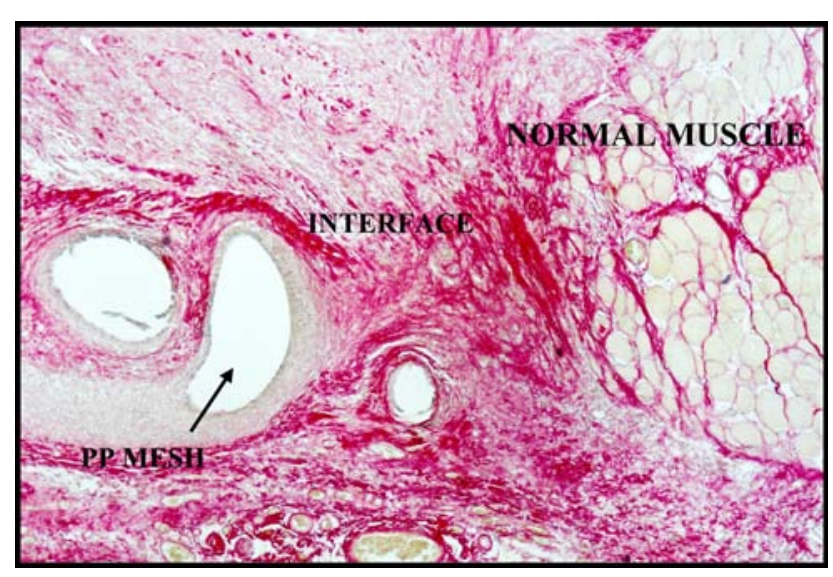

FIGURE 2 - Histological section of rat from PP mesh group showing the interface where the images were trapped for morphometric evaluation consisted in quantitative analyses of the collagen, under staining with Sirius Red

\section{Statistical analysis}

The statistical significance was determined by the Mann-Whitney U test, the Kruskal-Wallis and ANOVA test. Significance was accepted at $\mathrm{p} \leq 0.05$.

\section{Results}

The postoperative period for all rats was uneventful, except in one animal on the peritoneum group. No wound infections were noted in any of the study animal. There was no difference in variation of mean body weight during the study, showing the homogeneousness of behavior of the groups, when comparing the preoperative and postoperative conditions, as shown on Table 1 . The behavior of histological evaluations of amount of collagen observed by light microscope was similar in both 
groups (Table 2). A difference in statistical analysis was seen only in peritoneum group ( $\mathrm{p} \leq 0.05)$, when it was we compared the median value between subgroups (day 7 vs. day 28).

TABLE 1 - Comparison of mean $\Delta \%$ of the rat body weight (g) on days 7 and 28

\begin{tabular}{lcc}
\hline & $\begin{array}{c}\text { Group I } \\
\text { (peritoneum) }\end{array}$ & $\begin{array}{c}\text { Group II } \\
\text { (mesh) }\end{array}$ \\
\hline Mean of $\Delta \%$ on day 7 & -3.22 & -2.72 \\
Mean of $\Delta \%$ on day 28 & 3.01 & 4.76 \\
\hline
\end{tabular}

Group 1 (peritoneum) on day 7 vs. day 28: $p=0.013 *$

Group 2 (polypropylene) on day 7 vs. on day 28: $p=0.002 *$

TABLE 2 - Comparison of rats from groups I and II and their subgroups on days 7 and 28 after operation by mean values (\%) of collagen observed under the light microscope

\begin{tabular}{|c|c|c|c|c|}
\hline & \multicolumn{2}{|c|}{ Group 1 (BPP) } & \multicolumn{2}{|c|}{ Group 2 (PP mesh) } \\
\hline & $\begin{array}{l}\text { 7th PO } \\
(n=10)\end{array}$ & $\begin{array}{l}\text { 28th PO } \\
\qquad(n=9)\end{array}$ & $\begin{array}{l}\text { 7th PO } \\
(n=10)\end{array}$ & $\begin{array}{l}\text { 28th PO } \\
(n=10)\end{array}$ \\
\hline Mea & 27.55 & 35.43 & 29.28 & 33.40 \\
\hline Median & 26.13 & $34.70^{*}$ & 30.17 & 34.10 \\
\hline
\end{tabular}

Group 1 on day 7 vs. on day 28: p $=0.006 *$ (day $7<$ day 28)

Group 2 on day 7 vs. on day 28: p $=0.105$ (NS)

Group 1 vs. Group 2 on day 7: p = 0.53 (NS)

Group 1 vs. Group 2 on day 28: p = 0.55 (NS)

\section{Discussion}

Knitted polypropylene mesh is commonly used to support the hernia repair since it was introduced in medical practice, ${ }^{28}$ and it can therefore set as "control" (standard treatment) in the experimental studies ${ }^{29}$. Based on this, we decided to use PP mesh for comparison with BPP in our investigation. Although currently used in animal experimental studies, synthetic non-absorbable mesh (mainly polypropylene) results in a great number of complications in clinical practice as related previously. Moreover, in developing countries daily practice, they may be costly for routine use in hernioplasty. The biological material would appear to be ideal for bridging some troubles. Autologous tissue (mainly fascia lata) has been used, but presents the disadvantage of requiring a secondary incision with prolonging operation time. Homologous grafts have been an option for hernia repair and preserved human dura mater is commercially available for the clinical application. Previous study in guinea pigs involving electron micrographs documentation of Lyodura ${ }^{\circledR}$ implantation has shown that it should be considered in surgical arsenal for diaphragm and abdominal wall repair ${ }^{30}$. Meanwhile, it has been largely noticed in health websites the association between Creutzfeldt--Jakob disease transmission and the use of cadaveric human dura mater. It might lead to limitation of worldwide use. Aside this, a lengthy and complicated process of preparing and storage, including radiation and lyophilization technique, may also contribute for reducing clinical use. Heterologous tissue has advantages. They can be trapped from animals with no damage to the patient and, therefore, no biological costs enhanced. In theory, there is risk of rejection and it is up to material nature and preparation processes. Thus, the choice of the donor animal and the decrease of antigenicity play a central role in heterografts employment. The bovine parietal peritoneum can be applied as surgical mesh with advantages when compared with other biological materials, especially lower cost. Besides, it is a soft, malleable membrane that makes the BPP easy to deal and adjustment in application. Previous studies of BPP in dogs had showed adequate integration in host-tissue ${ }^{24,25}$. The resistance of BPP was already tested only in natura and it was superior to peritoneum from pigs, dogs and horses $^{27}$. After implantation of BPP and PP meshes, the amount of collagen increased on postoperative day 28, as compared to day 7, showing that BPP (as PP) allows good ingrowth of fibrocollagenous tissue through wound healing. It could even see as an indirect sign of lack of hostmesh rejection. However, BPP is a xenograft and it is not possible to draw it from the results of the present study and further research is needed to verify it.

\section{Conclusion}

This experimental investigation provides evidence that BPP can be used effectively in hernioplasty in a rat ventral hernia model as showed by its morph metric integration. However, we emphasize that a long-term follow-up study, utilizing others animals and looking for specific aspects of rejection may be conducting for better elucidation and validation of using of BPP in clinical researches.

\section{References}

1. Scoot NW, Webb K, Go PMNYH, Ross, S.J.; Grant, A.M. On behavior the hernia trialists collaboration: open mesh versus non-mesh repair of inguinal hernia (Cochrane review). Oxford: Update Software; 2001.

2. Pavlidis TE, Atmatzidis KS, Lazaridis CN, Papaziogas BT, Makris JG, Papaziogas TB. Comparison between modern mesh and conventional non-mesh methods of inguinal hernia repair. Minerva Chir. 2002;57:7-12.

3. Ahmad M, Niaz WA, Hussain A, Saeeduddin A. Polypropylene mesh repair of incisional hernia. J Coll Physicians Surg Pak. 2003;13:440-2.

4. Bellón JM, Buján J, Contreras LA, Martin ACS, Jurado F. Comparison of a new type of polytetrafluoroethylene patch (micro mesh) and polypropylene prosthesis (marlex) for repair of abdominal wall defects. J Am Coll Surg. 1996;183:11-8.

5. Klinge U, Klosterhalfen B, Ottinger AP, Junge K, schumpelick V. PVDF as a new polymer for the construction of surgical meshes. Biomaterials. 2002;23:3487-93.

6. Besim H, Yalcin Y, Hamamci O, Arslan K, Sonisik M, Korkmaz A, Erdogan S. Prevention of intraabdominal adhesions produced by polypropylene mesh. Eur Surg Res. 2002;34:239-43. 
7. Leber GE, Garb JL, Alexander AI, Reed WP. Long-term complications associated with prosthetic repair of incisional hernias. Arch Surg. 1998;133:378-82.

8. Aldridge AJ, Simson JN. Erosion and perforation of colon by synthetic mesh in a recurrent paracolostomy hernia. Hernia 2001;5:110-2.

9. Losanoff JE, Richman BW, Jones JW. Enterocolocutaneous fistula: a late consequence of polypropylene mesh abdominal wall repair: case report and review of the literature. Hernia. 2002;6:144-7.

10. Korenkov M, Sauerland S, Arndt M, Bograd L, Neugebauer EA, Troidl H. Randomized clinical trial of suture repair, polypropylene mesh or autodermal hernioplasty for incisional hernia. Br J Surg. 2002;89:50-6.

11. Geoffrey EL, Garb JL, Alexander AI, Reed WP. Longterm complications associated with prosthetic repair of incisional hernias. Arch Surg. 1998;133:378-82.

12. Gruen RL, Morrison WA, Vellar ID. The tensor fasciae latae myocutaneous flap closure of major chest and abdominal wall defects. Aust N Z J Surg. 1998;68:666-9.

13. Jenkins SD, Klamer TW, Parteka JJ, Condom RE. A comparison of prosthetic materials used to repair abdominal wall defects. Surgery. 1983;94:392-7.

14. Kama NA, Coskun T, Yavuz H, Doganay M, Reis E, Akat AZ. Autologous skin graft, human dura mater and polypropylene mesh for the repair of ventral abdominal hernias: an experimental study. Eur J Surg. 1999;165:1080-5.

15. Baykal A, Yorganci K, Sokmensuer C, Hamaloglu E, Renda N, Sayek I. An experimental study of the adhesive potential of different meshes. Eur J Surg. 2000;166:490-4.

16. Paulino LAF. Pericardio bovino fixado em glutaraldeído como substituto peritônio-aponeutótico. Rev Bras Cir. 1987;77:21-4.

17. Steinau G, Dreuw B, Schleef J, Schumpelick V. Diaphragm replacement: an experimental animal study. Langenbecks Arch Chir. 1997;382:74-8.

18. Kapan S, Kapan M, Goksoy E, Karabicak I, Oktar, H. Comparison of PTFE, pericardium bovine and fascia lata for repair of incisional hernia in rat model, experimental study Hernia. 2003;7:39-43
19. Cataldo MLS, Silva Al, Guerra AJ. Emprego do saco herniário na correção cirúrgica das hérnias incisionais longitudinais - aspectos experimentais no cão. Rev Col Bras Cir. 1981;8:167-70.

20. Silva AL. Uso de saco herniário no reforço da hernioplastia inguinal. Rev Col Bras Cir. 1995;22:153-4.

21. Szabo A, Haj M, Waxsman I, Eitan A. Evaluation of seprafilm and amniotic membrane as adhesion prophylaxis in mesh repair of abdominal wall hernia in rats. Eur Sur Res. 2000:32:125-8.

22. Abraham GA, Murray J, Billiar, K, Sullivan SJ. Evaluation of the porcine intestinal collagen layer as a biomaterial. J Biomed Mater Res. 2000;51:442-52.

23. Yeliseyev NT. Application of preserved heteroperitoneum for plastic operation of postoperational ventral hernia. Acta Chir Plast. 1970;12:77-84.

24. Daleck CR, Alessi AC, Costa-Neto JM, Daleck CLM, Padilha-Filho JC. Substituição de um retalho diafragmático de cão por peritônio de bovino conservado em glicerina: estudo experimental. Ars Vet. 1988;4:53-61.

25. Daleck CR, Daleck CLM, Padilha-Filho JG, Costa-Neto JM. Reparação de hérnia perineal em cães com peritônio de bovino conservado em glicerina. Ciênc Rural. 1992;22:179-83.

26. Costa-Neto JM, Daleck CR, Alessi AC, Braccialli CS. Tenoplastia experimental do calcâneo em cães com peritônio bovino conservado em glicerina. Ciênc Rural. 1999;29:697-703.

27. Batista LC, Daleck CR, Shimano AC, Alessi AC, Abrahão MS. Estudo comparativo da resistência à tração do peritônio (bovino, eqüino, suíno e canino) a fresco e conservado em glicerina. Braz J Vet Res Anim Sci. 1996;33(suppl.):305-12.

28. Usher FC, Wallace AS. Tissue reaction to plastics. Arch Surg. 1958;76:997-9.

29. Bellón JM, Buján J, Contreras LA, Martin ACS, Jurado F. Comparison of a new type of polytetrafluoroethylene patch (Mycro Mesh) and polypropylene prosthesis (Marlex) for repair of abdominal wall defects. J Am Coll Surg. 1996;183:11-8.

30. Gomez NA, Moral A, Rubio G, Burgos R, Diaz J, Leon C. Lyophilized human dura-mater vs. pericardium in the repair of abdominal wall defects: experimental study in guinea pigs. Arq Bras Cir Dig. 1994;9:38-41.

\section{Correspondence:}

Eduardo Lemos De Souza Bastos

Rua Carlos Botelho, 246

17515-240 Marília-SP Brazil

Phone/Fax: (55 14) 3433-1715

edbastos@unimedmarilia.com.br
Conflict of interest: none Financial source: none

Received: April 11, 2006

Review: May 10, 2006

Accepted: June 14, 2006

\section{How to cite this article:}

Bastos ELS, Fagundes DJ, Taha MO, Novo NF, Juliano Y, Simões MJ, Silvado RAB. The role of preserved bovine peritoneum in rats ventral hernia: a histological evaluation. Acta Cir Bras. [serial on the Internet] 2006 Sept-Oct;21(5). Available from URL: http://www.scielo.br/acb 